\title{
Immunological Situation and Interferences in the Acquisition and Production of Vaccines in Angola-Africa
}

\author{
Abiude Paulino* \\ CEO - Eduiba Projects Scientific Consultant and Researcher, Luanda, Angola \\ *Corresponding Author: Abiude Paulino, CEO - Eduiba Projects Scientific \\ Consultant and Researcher, Luanda, Angola.
}

DOI: 10.31080/ASMI.2020.03.0652

The lack of a contingency plan and a specific vaccine immunization model in Africa, the lack of hospital centers at municipal and commune level, especially in Angola, which goes according to the human, environmental and social reality of the local communities, has been a key factor in the process of stability, expansion and public health security in many African regions, above all in Angola.

The research I have conducted has closely observed the way vaccine immunization programs are directed in many countries in Africa where the ministries of health of these governments adapt their national immunization programs in accordance with the World Health Organization (WHO) plan and contingency program.

These and many other factors have led me to take a close look at the health sector and the immunization program currently in place in Africa, which in turn has given me a step-by-step look at and analyze the following factors in depth:

- The urgent need for the creation of permanent logistic centers for the storage of various vaccines at national level.

- The regularization of customs loads of imports of various hospital materials.

- The lack of scientific research laboratories and vaccine production.

Given the current emergence of various diseases on the continent, Angola has been one of the countries at the African level that in the last 5 years, included in its governance plan the urgent need to build large health centers at the national and regional level, but still the financial value that the Ministry of Health receives from the general budget of the Angolan state, does not meet the urgent
Received: April 29, 2020

Published: July 25, 2020

(C) All rights are reserved by Abiude Paulino. needs capable of dealing with an intervention with more effectiveness and responsibility at the level of the public health sector and far below that recommended by the World Health Organization (WHO).

Thus, we find that the lack of serious investment in the public health sector in Angola has been since the years after independence, particularly in the years 1975 and after the peace agreement in 2002 , so much so that the population as a whole does not benefit from a public health insurance what we consider to be a great threat to life, with the country has children who in the past gave their lives for national reconciliation and peace in Angola.

This group of former combatants are today the most vulnerable to the great problems of the public health, many of them today face serious mental situations, chronic infections serious as diabetes among other tropical diseases that given the time and the way were exposed to nature and subjected to war work originated from there diseases and infections which in turn spread to a number of families considered to belong to the degree of kinship.

With this, the private sector has taken advantage of the fragility of the state, seeking to ensure a medical assistance but robust, yet very expensive and not according to condition everyone's financials.

From this, we analyzed until that due to the lack of seriousness in public health, many occur to the public and private health services of Portugal, Namibia and South Africa for guaranteeing the better hospital and medical care conditions and an insurance plan but low than Angola's. 


\section{National immunization}

The efforts are seen by all the provinces of the country. However, Angola is still 70\% dependent of the immunization programs outlined by the World Health Organization (WHO).

Therefore, because of the lack of resolution of the above mentioned factors, for which we highlight.

The factor: Absence of the plan to build a logistical network for vaccine storage and the lack of production laboratories.

In the event of an epidemic of urgent national combat in the health sector in sight, the chances of epidemic control are few, if any, or even nil, of the times there have been epidemics in Angola, the Angolan state has never been able to fight the situation without the guaranteed private aid, governments, organizations and very large financial loans which in turn, they've always put the country in the ranking of the world's most debtor countries.

We are facing a reality that must be analyzed in depth, although the factor climate is an insurance cover that can alleviate the epidemiological but serious situations in Africa as the coronavirus, above all Angola and other countries of the region but hot of the continent.

Faced with the current outbreak of disease in Africa due to lack of contingency plans for national immunization on time and ready, Africa may be on the brink of living a serious epidemic that may be considered a pandemic for lack of inclusion and seriousness of the above factors and why international immunization plans outlined by the WHO often do not accord with the social and human reality of the African communities.

Therefore, many African countries are dependent on the supply of vaccines and the imports of medicines that arrive in the countries through the United Nations, and by not the local production of vaccines, makes Africa fragile in terms of capacity to response and effectiveness in addressing the challenges that the health sector presents.

The social and regional destabilization that many African countries experience, makes also threatened public health on the continent.
The lack of immunization animal, the lack of animal feed production centers, the lack of laboratories certified and adapted to international research standards, have been major threat factors to public health in Africa.

\section{Final Consideration}

In this research report, I also intend to alert and invite the scientists, researchers, and vaccine producers to seriously bet on Africa; I guarantee technical and legal support, and the indication of land concession to those companies or individuals who want to invest in Angola in the health among other branches in partnership with EDUIBA PROJECTOS.

Africa does not need much, she has everything, Africa just needs the good and of good initiatives.

\section{Assets from publication with us}

- Prompt Acknowledgement after receiving the article

- Thorough Double blinded peer review

- Rapid Publication

- Issue of Publication Certificate

- High visibility of your Published work

Website: www.actascientific.com/

Submit Article: www.actascientific.com/submission.php

Email us: editor@actascientific.com

Contact us: +919182824667 